Dimova ED, Swanson V \& Evans JMM , Gender and diet management in type 2 diabetes, Chronic Illness 2021;17(4):362-376. Copyright (c) The Authors 2019. Reprinted by permission of SAGE Publications. DOI: $10.1177 / 1742395319873375$ Reuse is restricted to non-commercial and no derivative uses.

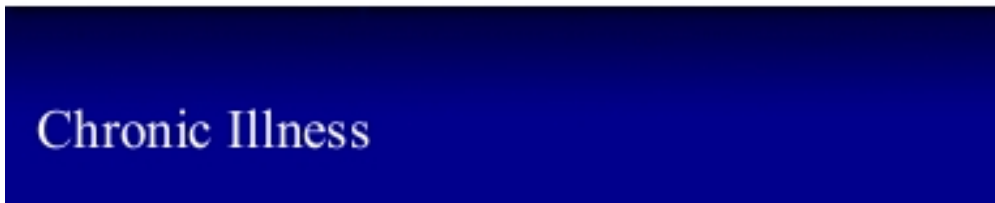

\title{
Gender and diet management in type 2 diabetes
}

\begin{tabular}{|c|c|}
\hline Journal: & Chronic Illness \\
\hline Manuscript ID & CHI-19-0043.R1 \\
\hline Manuscript Type: & Original Article \\
\hline Keywords: & type 2 diabetes, diet management, gender, family, interviews \\
\hline Abstract: & $\begin{array}{l}\text { Introduction: Type } 2 \text { diabetes is a chronic health condition that requires } \\
\text { ongoing self-management. This often includes changes in diet, which } \\
\text { may be open to influences from relatives. Family support in terms of } \\
\text { diet may be linked with gender and the assumption that meal } \\
\text { preparation is a traditionally female activity. This article looks at the role } \\
\text { of gender in diet management in people with type } 2 \text { diabetes and their } \\
\text { relatives. } \\
\text { Methods: Seventeen semi-structured interviews were conducted with } 23 \\
\text { participants ( } 10 \text { people with type } 2 \text { diabetes, } 13 \text { relatives of people with } \\
\text { type } 2 \text { diabetes) in Scotland, UK. The aim was to uncover changes } \\
\text { people have made to their diet following diagnosis of type } 2 \text { diabetes in } \\
\text { oneself or a family member. Data were analysed using Framework } \\
\text { Approach. } \\
\text { Findings: Female relatives were more likely to manage the patient's diet } \\
\text { while male relatives provided support but were less likely to monitor the } \\
\text { person's diet. Female patients may prioritise the needs of their family } \\
\text { while male patients are more likely to rely on their female relatives in } \\
\text { terms of diet management. } \\
\text { Discussion: The study findings have implications for family-based } \\
\text { interventions as gender may play a crucial role in the management of } \\
\text { type } 2 \text { diabetes. }\end{array}$ \\
\hline
\end{tabular}

\section{SCHOLARONE" Manuscripts}




\section{Gender and diet management in type 2 diabetes}

\section{Abstract}

3 Introduction: Type 2 diabetes is a chronic health condition that requires ongoing self-management.

4 This often includes changes in diet, which may be open to influences from relatives. Family support

5 in terms of diet may be linked with gender and the assumption that meal preparation is a

6 traditionally female activity. This article looks at the role of gender in diet management in people

7 with type 2 diabetes and their relatives.

8 Methods: Seventeen semi-structured interviews were conducted with 23 participants (10 people

9 with type 2 diabetes, 13 relatives of people with type 2 diabetes) in Scotland, UK. The aim was to 10 uncover changes people have made to their diet following diagnosis of type 2 diabetes in oneself or 11 a family member. Data were analysed using Framework Approach.

Findings: Female relatives were more likely to manage the patient's diet while male relatives provided support but were less likely to monitor the person's diet. Female patients may prioritise the needs of their family while male patients are more likely to rely on their female relatives in terms of diet management.

Discussion: The study findings have implications for family-based interventions as gender may play a crucial role in the management of type 2 diabetes.

Key words: type 2 diabetes, diet management, family, gender, interviews.

\section{Introduction}

20 Type 2 diabetes is a chronic health condition that requires ongoing self-management in order to

21 minimise negative health consequences such as developing comorbidities ${ }^{1}$. People with type 2

22 diabetes are advised to monitor their diet in order to maintain certain blood-glucose levels ${ }^{2}$. A

23 "healthy and balanced" diet that is rich in fibre and low in salt and sugar is recommended². Diabetes

24 self-management can be facilitated by relatives and partners who can provide advice and support, 25 and assist with daily activities ${ }^{3,4}$. This is particularly relevant -to diet management, which as a shared 26 activity, may be more open to influences from family members than other behaviours 4,5 . However, 27 family support in terms of diet may be linked with gender and the assumption that meal preparation is a traditionally female activity ${ }^{6,7}$. This may be particularly relevant to middle-aged and older women who are less likely to rely on spouses with everyday activities ${ }^{8}$. However, in families in which women are ill, although we might expect a narrowing in the gender gap in the division of these activities and men engaging in meal preparation, research shows that this is often not the case. 
32 Previous research in diabetes suggests specific gender differences in relation to diet management.

33 For example, Maclean ${ }^{9}$ found that married men with type 1 diabetes were at "an advantage" because in almost all cases of their sample the wives prepared meals, which conformed to the prescribed diet. Women with type 1 diabetes in Maclean's ${ }^{9}$ study, however, often had to balance their personal needs with the food needs of their family. More recent research shows a similar pattern. A systematic review by Li et al. ${ }^{10}$ found that women with type 2 diabetes often prioritise the needs of their family and show low dependence on their spouses-adopt multicare-giving responsibilities $^{10,11}$. Men, on the other hand, are more likely to be dependent on their spouses in relation to diet management ${ }^{10}$. This may also be relevant to men with type 2 diabetes who live with their daughters, as the daughters may adopt a caring role and assist them in their diet management.

42 Traditional gender role orientation in terms of meal preparation and diabetes has been reported in 43 different cultures (African-Americans ${ }^{12}$; Japan ${ }^{10}$; Canada $^{9}$ ). However, research on the role of gender 44 in relation to diet management and type 2 diabetes in the UK is limited. They often subjugate their 45 own needs for the needs of their family members and cook separate meals for themselves ${ }^{11}$. As a 46 result, women show low dependence on their spouses and do not identify their spouse as a source 47 of support ${ }^{10-12}$. On the other hand, men with type 2 diabetes are more likely to be dependent on 48 their spouses in relation to diet management and identify their wife as a main source of support ${ }^{11,12}$. 49 This is particularly problematic in respect to morbidity and mortality: women with type 2 diabetes 50 are at increased risk of death from cardiovascular disease and stroke, compared to men ${ }^{13,14}$. In 51 addition, women with caregiving responsibilities may experience higher levels of perceived burden 52 which can lead to poor physical and mental health ${ }^{15}$. Traditional gender role orientation in relation 53 to diet management may be particularly prominent in certain cultures. For example, in a Mexican 54 sample, women were viewed as "food preparers" so they took the responsibility for managing a 55 patient's diet ${ }^{16}$. Similarly, a qualitative study conducted in Pakistan showed that men view diet 56 change as a matter for wives whose job it is to prepare the right food ${ }^{17}$. In an African-American 57 sample, traditional gender roles extended to daughters, who were the main providers of diabetes58 related care, including diet management ${ }^{18}$.

59 In the UK, there has been a decline in traditional gender role perceptions with $72 \%$ of respondents in 602019 disagreeing that women should be viewed as homemakers ${ }^{19}$. However, there is still a gap in 61 understanding how gender plays a role in diet management following diagnosis of type 2 diabetes in 62 oneself or a family member. In addition, the majority of previous research has explored this from the 63 perspective of the person with type 2 diabetes. The experiences of family members and the role 64 gender plays in providing support for someone with type 2 diabetes are seldom the focus of 
research. A better understanding of traditional gender roles in diet management can provide insight into ways to improve self-care in patients and provide support for relatives.

67 The objective of this article is to describe the role of gender in diet management in response to a

68 recent diagnosis of type 2 diabetes. The study builds on previous research by presenting the views of 69 both patients with type 2 diabetes and relatives of such patients.

71 This article looks at the role of gender in diet management in people with type 2 diabetes and their 72 family members.

\section{Methods}

74 Ethical approval for this study was granted by the University of Stirling, School of Health Sciences 75 ethics committee (SREC 15/16, Paper No. 37, version $17^{\text {th }}$ Oct. 2015).

76 This was a qualitative study, conducted in Scotland (UK), which explored the way people respond to and cope with diagnosis of type 2 diabetes in oneself or in a family member. The aim was to interview people who had recently been diagnosed with type 2 diabetes and at least one of their non-diabetic family members or a spouse/partner-in order to uncover people's shared experiences of diabetes. A recent diagnosis in oneself or a family member decreased the risk of recall bias and optimised the chance of participants recollecting specific changes that occurred as a result of the diagnosis. This article presents the findings related to diet management.

\section{Recruitment}

84 Recruitment was carried out through community outreach in Forth Valley, Scotland. Posters and 85 flyers, explaining the study, were distributed at 109 community locations, such as community centres, libraries, charity shops, bowling clubs, golf clubs, local post office branches and the Interested participants were invited to contact the researcher by using the given email address or phone number.People who expressed interest were screened for eligibility on the basis of the following criteria: 1) over the age of 18 years; 2) able to speak and write in English; 3) a recent diagnosis of type 2 diabetes in oneself or a family member. As type 2 diabetes is a chronic condition, people's perception of what constitutes a recent diagnosis may differ so a specific timeframe was not used. If a participant was eligible to take part, they were asked to nominate one non-diabetic 
diabetes if it was the family member who got in touch). The participant was then asked to provide their family member with the study flyer and the researcher's contact details.

\section{Data collection}

Semi-structured face to face or phone (where face to face was not possible) interviews were conducted with people with type 2 diabetes and relatives of people with type 2 diabetes. Before the start of the interview, participants were given the opportunity to ask questions before written informed consent was obtained. After that participants were asked toFirst, participants completed a brief questionnaire that collected information about duration of type 2 diabetes, route to diagnosis, relationship with the person with type 2 diabetes (for relatives), gender, age, highest education, employment status, relationship status and postcode to enable calculation of the Scottish Index of Multiple Deprivation (SIMD) or full address if the participant wanted to receive information about study findings. The SIMD is used to identify areas of multiple deprivation in Scotland by ranking small areas from most deprived (ranked 1 ) to least deprived (ranked 10) ${ }^{13}$. The interview started with questions asking participants about how they were diagnosed with type 2 diabetes or how they found out their relative had type 2 diabetes. After that they moved on to ask people about changes in their life since the diagnosis of type 2 diabetes in themselves or in a family member. The interview aimed to uncover changes in participants' lives since the diagnosis of type 2 diabetes in themselves or in a family member. The topic areas included psychological changes in perceptions of diabetes severity and risk of complications (or developing type 2 diabetes in relatives), behaviour changes in relation to physical activity, diet and responsibilities, communication about type 2 diabetes and suggestions for diabetes service improvements and intervention design. Example questions in relation to diet included: "What changes in relation to diet have you made since the diagnosis?", "What barriers have you experienced?", "Tell me more about your family and what they do in relation to your diet?". The interviews were semi-structured so questions varied depending on the participant's response. Probes included: "How easy was it to change your diet?", "Do you and your partner do anything differently together?", "Have your responsibilities in the house changed?".

An important consideration for the study was whether to interview members of the same family together or separately. Joint interviews are useful when the interviews seek to explore the way people collectively cope with illness. Individual interviews are useful when each individual's perspective is sought. Although the initial aim was to interview people together, not all participants could agree on a suitable time, so some members of the same family were interviewed separately. In some cases, the interviews also included only one member of a family as other family members did not agree to take part. The decision not to exclude people whose family members were unable to take part was influenced bypractical considerations, such as time and money three reasons 1) the 
study did not aim to explore discrepancies in the views of men and women from the same family; 2) to reduce the risk of coercion from family members who want to take part and 3) practical considerations, such as time and money, as this study was part of a PhD project.-. Although a family interview would shed light into the way people interact when talking about diet management, individual perspectives are important as in some cases people may be more open if family members are not present.

The interviews were conducted by a female researcher with training and experience in collecting qualitative data (EDD). Data collection continued until data saturation was reached. We conceptualised data saturation in terms of the study target group and quality and quantity of information. The study participants represented a group with specific characteristics (i.e. recent diagnosis of type 2 diabetes in oneself or a family member, living in the UK). Participants openly talked about their experience, which enabled the researcher to gain sufficient information and notice similarities (or differences) in experiences throughout the data collection process. In order to avoid data redundancy, saturation was deemed to have been achieved when no new data emerged.

\section{Data analysis}

The interviews were audio-recorded, transcribed verbatim and checked against the recordings for accuracy. All information was anonymised and participants were given study numbers. The file linking the study numbers with participants' details was kept separately from the recordings and transcripts. Data were analysed using Framework Approach, which is based on the assumption that the researcher stays close to the original data in order to "capture, portray and explain the social worlds of the people under study" (p.279) ${ }^{14}$. This approach was chosen because it is better adapted to research that has specific questions and a priori issues that need to be explored and as it helps to

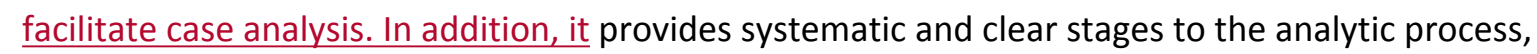
thus allowing people to see the stages, by which the results are obtained ${ }^{15}$. This transparency ensures trustworthiness of data, especially in terms of credibility and confirmability. In addition, $\underline{\text { having a clear process increases study transferability and dependability making it easier for others to }}$ explore the consistency of findings and compare them to other contexts and conditions. Analysis followed the data analysis stages, suggested by Spencer et al. ${ }^{14}$, which include familiarisation, constructing an initial framework, indexing and sorting, reviewing data extracts, data summaries, developing categories, mapping linkages, and providing explanations and interpretations. The interview questions were initially used to guide data analysis. During the developing categories stage, while detecting elements initial themes had in common, it became apparent that participants' 
163

164

responses in relation to diet management appeared to differ between men and women. This enabled the identification of the themes presented in this article. Analysis was conducted by the primary author. Another author with extensive experience in qualitative research (VS) reviewed the data analysis stages to ensure that the final themes emerged from the data.

\section{Findings}

Forty two people showed interest in the study by contacting the researcher over phone or email (22 people with type 2 diabetes, 20 relatives). These were screened by asking them when they/their relative was diagnosed with type 2 diabetes and if they considered themselves/their relative to be newly diagnosed. Twenty three participants took part in 17 semi-structured interviews. Sample characteristics are presented in Table 1.

\section{Insert Table 1 about here}

Thirteen of the interviews were individual and four included the person with type 2 diabetes and their relative(s) (Table 1). Ten were people with type 2 diabetes and 13 were relatives of people with type 2 diabetes. Relationships included two families (father, mother, two daughters; father, mother, daughter); a mother-daughter dyad; and three couples. The remainder were either a person with type 2 diabetes or a relative whose family members were unable to take part. Details about the relationships between participants and how they were interviewed are presented in Table 2. Interviews were conducted between November 2015 and March 2016 and took place in participants' homes $(N=6)$, private rooms at University of Stirling $(N=6)$, a local hotel $(N=1)$, a local library $(N=1)$ and a private office at a participant's workplace $(\mathrm{N}=1)$, and over the phone with the researcher in a private room ( $\mathrm{N}=2$ ). Interviews lasted between 25 and 85 minutes. Participants were given $£ 10$ as reimbursement for participation.

\#seft Iable 1 about here

Participants' characteristics are displayed in Table 2.

Insert Table 2 about here 
195 Data analysis yielded two emergentthemes addressed by both people with type 2 diabetes and their relatives: Women - taking responsibility for diet management, and Men - "going along" with the new diet. Women - more likely to adopt a caring role and additional responsibilities, and Men - more likely to provide support and advice.

\section{Women - more likely to adopt a caring role and additional responsibilitiestaking} responsibility for diet management

Virtually all relatives of people with type 2 diabetes talked about supporting diabetes selfmanagement. However, compared to men, women more often talked about a desire to manage the person's condition, take an active role in trying to prescribe a specific diet regimen and ensure the person with type 2 diabetes adheres to it. Female relatives of people with type 2 diabetes talked aboutsearching for information on dietay management by bungand borrowing books, and

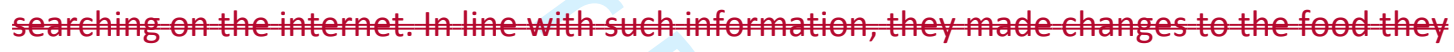
cooked:

Similarly, daughters of men with type 2 diabetes were proactive in obtaining information and adjusting their fathers' diet accordingly: Female relatives of people with type 2 diabetes talked about searching for information on dietary management by buying and borrowing books, and searching on the internet. In line with such information, they made changes to the food they cooked:

"The female always has a bit of a problem because they usually stereotypically are the ones responsible for shopping and cooking food, so you've got to manage this condition for them, at least for one meal a day." R5, wife of a man with type 2 diabetes

\footnotetext{
"Just trying to research food for dad, trying to make him better meals. Make him different sandwiches all the time at work." R4, daughter, lives with father with type 2 diabetesR3, daughter
}

This was not necessarily a change in roles as in both cases the women were responsible for meal preparation before the diagnosis of type 2 diabetes. However, they perceived it to be their role to change the meals to align with diabetes-related recommendations. This perceived need to manage the person's diet often led to additional responsibilities and affected other aspects of the women's lives: 
"I make sure what he [father] has every day: "you are not allowed to eat that anymore" so it's quite hard to have to balance my university with all this watching his diet as well as mine, and they're just jumbled up with each other." R6, daughter, lives apart from father with type 2 diabetes

In other cases, it presented a difficulty in managing the diet of other family members:

"Yeah, I try and buy less sweet things but for me, the dilemma is very difficult, because our daughter is underweight and doesn't eat very much at all and she is much more likely to eat biscuits and cakes and sweets than anything else, so it's trying to balance her need to have a high calorie [diet]." R5, wife of a man with type 2 diabetes

The perceived need to monitor the person's behaviour was described as "policing" where women felt they need to ensure the patients ey comply with the specific diabetes-related diet regimen:

"... so for me one of the changes is knowing what's supportive and what's not, so the challenge existing is trying to police and say "you can't do this and you can't do that, you know, do you really need to eat that or should you be eating that, you know" because it's not gonna help, you know, 'cause you can just eat it when I'm not there, if you wanted to, but I find it hard to resist the urge to interfere." $\mathrm{R} 5$, wife of a man with type 2 diabetes

"...I think he eats sweet packets so that gives me a reason to shout at him for it." R6, daughter, lives apart from father with type 2 diabetes

The second quote comes from the daughter of a person with type 2 diabetes and suggests a form of role reversal where children tell parents what to do. Although it is perceived as expected for children to look after parents at a certain stage of life, type 2 diabetes appeared to be a trigger for this role reversal:

"I would say usually, growing up your dad looks after you, but I'm suddenly thinking I need to look more after my dad as well." R2, daughter, lives apart from father with type 2 diabetes

One woman with type 2 diabetes talked about the diagnosis as the moment when children may realise they need to look after their parents:

"...I suppose because I had the diagnosis and because of the potential for strokes and things like that, you can tell for the very first time they are thinking of me as someone who can die." P6, a woman with type 2 diabetes, lives alone 
254 In some families, the roles before diagnosis did not align with traditional roles and assumptions 255 where the wife does most of the cooking. However, diagnosis of type 2 diabetes in the husband 256 appeared to affect this and change relationship balance:

257 "I think probably the balance in our relationship has changed. I would probably see me having 258 more of a caring role than I had before. And I think like [husband]. said, [husband] used to do 259 all the cooking and the balance in that has changed." R7, wife of a man with type 2 diabetes 260 "She [wife] likes caring for people, you know, she likes caring for me so in fact one thing, here 261 you go, that's one thing that's changed, she does a lot more cooking than she used to (...) she is 262 not a great cook but she is trying, she is doing a lot more of it to try and make things easier for 263 me" P9, a man with type 2 diabetes, lives with family

264 Although in these cases, the men may have experienced diabetes-related symptoms that 265 interfered with their ability to continue cooking, this was not reported by women with type 2 diabetes. Women with type 2 diabetes continued to perceive that it was their responsibility to prepare meals, which in some cases added additional diet-related responsibilities, such as

Women did not always live with the person with type 2 diabetes. In one case (see R6 earlier), the daughter phoned her father every day to monitor what he has eaten that day. In other cases, the likelihood of women taking an active role in the management of the person's diet appeared to be influenced by geographical closeness. In a few of the cases, women did not live with the person with type 2 diabetes.Although not directly explored, it appeared that these women managed the patient's diet the likelihood of women taking an active role in the management of the person's diet appeared to be influenced by geographical closeness. If relatives did not live with the person with type 2 diabetes, they managed their diet only on the occasions when they visited them:

280 "I am much less willing to offer him cakes or biscuits or anything like that... erm...I am much more focused on giving him salads." R1, mother, lives separate from son with type 2 diabetes 
283 Men - "going along" with the new dietmore likely to provide support and rely on relatives

284 Compared to the women in this sample, men provided support for their relatives with type 2

285 diabetes but were less likely to actively engage intake responsibility for managing their relatives' diet

286 management. The two male partners, who took part in this study, were both understanding of the

287 changes required in their wives' diet.Men were understanding of the fact that their relative with

288 type 2 diabetes needs to adopt diet changes and they expressed willingness to support them by

289 complying with the new diet regimen. Although both of them were "happy" to eat the meals their

290 wives prepared, one of them Men also provided advice and encouragement to their relative with

291 type 2 diabetes. However, they-made a clear distinction between themselves and their relatives his

292 needs and his wife's needs: by highlighting that the responsibility for diet management falls on the

293 person with type 2 diabetes:

294 "I mean I understand that, you know, what [wife]'s got, you know, I am quite happy to go

along with it and if I need to pig out or something, I'm probably gonna do it." R12, husband of a woman with type 2 diabetes

Only one son of a person with type 2 diabetes was interviewed. Similarly to the husband above, he provided advice and encouragement but he also distinguished himself from his father:

Sometimes, men believed that by complying with the new diet regimen, they have started eating

more healthily: The other husband in the sample believed his diet has changed as a result of him eating the food his wife with type 2 diabetes prepared:

"Yeah, as I say, she prepares the meals, so she prepares meals that are good so I eat more healthy because of what she is cooking." R8, husband of a woman with type 2 diabetes

However, this participant's perception differed from his wife's opinion:

"I make him be healthy but it's rubbish...he would just eat anything." P3, female with type 2 diabetes talking about her husband and providing support following diagnosis of type 2 diabetes. It further illustrates that women 
may take responsibility for managing the diet of the whole family by trying to "make" people eat

313 healthy food. These participants were interviewed separately so the difference in perception

314 could not be explored in more depth.

315 Men with type 2 diabetes also appeared to rely on their female relatives for diet management:

316 However, the interaction between a husband and wife below, where the husband has type 2

317 diabetes, suggests that women's perception of diabetes management may differ from that of

318 men's. He admitted to relying on his wife for diet management by saying:

319 "She is telling me what to eat, l eat it." P4, male with type 2 diabetes, lives with wife vegetables and carbohydrates he should have at each meal. In his account, it is clear he has made significant change to his diet. This man also appeared to avoid taking responsibility for his diabetes management and relying on his wife and other people to ensure he complies with the diet regimen:

"If I do something that's gonna make it [type 2 diabetes] worse, I'd hope somebody either the doctor or a nurse or [wife] would point out that I was doing it." P4, male with type 2 diabetes, lives with wife

However, in the interaction between him and his wife below, their views on the wider diabetes management differed. The wife's concern about her husband's health is obvious, which aligns with the woman's perception that she adopted a caring role following the diagnosis of type 2 diabetes:

Man with diabetes: "No butter in my potatoes now and oh... half the potatoes I used to take. But it's all within the allowances of the amount of carbohydrate lam meant to take of this or that, and I've never before eaten brown bread in my life so that's a difference. Anything else..." Wife: "No, I don't think...I don't feel like it's probably gonna make a huge difference. I think the big difference would be the exercise and the alcohol." R7, wife

Man with diabetes: "I told you earlier l like to have a good drink of whisky before I go to bed. She doesn't like me having a good drink of whisky before I go to bed because I prattle on." P4, male with type 2 diabetes

Wife: "No, I don't like it because of your health." R7, wife

This man also admitted to relying on his wife and other people to ensure he complies with the diet regimen:

"If I do something that's gonna make it [type 2 diabetes] worse, I'd hope somebody either the doctor or a nurse or [wife] would point out that I was doing it." P4, male with type 2 diabetes 
345 The potential difference in perceived responsibility for and approach to diet management between men and women is illustrated below in a quote from a man who considered a

347 hypothetical situation where his wife, instead of him, had type 2 diabetes:

348 "I would've sort of wanted to be more supportive but I wouldn't have got five textbooks and all

that kind of stuff." P2, male with type 2 diabetes, lives with family

350 There was only one man with type 2 diabetes in the current study who said his wife did not 351 change her diet to support him in his diet management:

"I think initially I probably drove her quite mad with my weighing portions and so on, I think because she wasn't doing it. I think she found that a bit irritating but beyond that she was

quite accommodating". P10, male with type 2 diabetes, lives with wife

\section{Discussion}

356 The findings in this article illuminate the role of gender in diet management for people with type 2

357 diabetes and their families. The study found that female relatives are more likely to take

358 responsibility for ensuring the person with type 2 diabetes conforms to the new diet. Similarly,

359 women with type 2 diabetes believed it is their responsibility to change their own diet, which

360 sometimes resulted in adopting additional responsibilities. Men, whether patients or relatives, were

361 more likely to comply with diet changes, initiated by women, rather than actively manage diet.

362 Women - taking responsibility for diet management

363 In this study, women talked about their desire to take an active role in diet management in response

364 to type 2 diabetes in their relative. This is consistent with previous findings that women are more

365 likely, compared to men, to assume responsibility for the management of their partner's diabetes ${ }^{23}$.

366 The behaviour exhibited by female relatives in the current sample can be described by using the 367 dyadic perspective of coping 24,25 , according to which patient and partner interact with each other to 368 mutually influence the adjustment process. Although the model of dyadic coping was developed in 369 partners/spouses, it could apply to other family dyads, such as parent-offspring dyads. Women 370 appear to engage in delegated dyadic coping, where they take over certain responsibilities to 371 alleviate the burden from the person with type 2 diabetes ${ }^{25}$. Women were more likely to monitor 372 other people's diet and engage in "policing", which in some cases resulted in a shift in relationship 373 balance (women adopting new roles) and role reversal (children telling parents what to do). Similar 374 patterns of behaviour in terms of family roles following diagnosis of diabetes have been observed 375 before ${ }^{16,18}$. Samuel-Hodge et al. ${ }^{18}$ explored diabetes management in African-Americans and found 376 that family members often engage in food policing. A potential explanation for women's increased 
377 likelihood to adopt a caregiving role is the suggestion that women internalise and take the caregiving

378 role more seriously ${ }^{26}$. This could be rooted in historical and social practices. Bourdieu ${ }^{27}$ argues that

379 traditional gender roles have been maintained through social construction and gender socialisation,

380 so women are considered to be inherently more likely to be caregivers. This is further confirmed by

381 recent findings that women may be viewed by their husbands as "food preparers"16,17. Bourdieu's27

382 suggestion also supports the finding that women with type 2 diabetes in the current study prioritised

383 the needs of their family thus adopting additional responsibilities (for example by cooking two

384 separate meals). Often, in families where men did the cooking, after their type 2 diabetes diagnosis

385 women's role in the kitchen appeared to increase. However, when women were the ones diagnosed

386 with type 2 diabetes, they continued to cook without men taking additional responsibilities in

$387 \quad$ relation to food preparation.

388 Although not directly explored in this study, the likelihood of relatives to adopt a caring role may be 389 influenced by geographical distance. According to Carmichael and Charles ${ }^{28}$ geographical distance is 390 a type of a "non-economic" factor that influences people's decision to adopt a caring role. Some of

391 the participants in the current study admitted that they thought more often about their relative with

392 type 2 diabetes but having work and family obligations and living far away from their relative,

393 interfered with their ability to provide support. However, female relatives talked about changing the 394 meals they prepare when their relative with type 2 diabetes visits them.

\section{Men - "going along" with the new diet}

396 Men, in the current sample, often talking about relying on their relatives to make diet changes and 397 "going along" with these changes was perceived as supportive behaviour. This can be explained in 398 terms of supportive dyadic coping where men provided support, advice and encouragement ${ }^{25}$. This 399 is consistent with previous research that men with type 2 diabetes are more likely to depend on 400 their spouses ${ }^{11,12}$. Del Rio-Lozano et al. ${ }^{26}$ suggests that men have a more flexible approach to care 401 and do not identify with the caregiving role. This may put men at a position of advantage because 402 their wives prepare meals that conform to the prescribed diet ${ }^{9}$. Although the sample of male 403 relatives in the current study was small, the results showed that men provided support and advice to 404 their relatives with type 2 diabetes but were less likely to feel responsible for monitoring the 405 patient's diet. We were not able to explore differences in support provision between husbands and sons but previous research suggests that there is a difference between sons' and husbands' 408 husbands see caregiving as an extension of their marital role ${ }^{29}$. 


\section{Implications}

411 The current study supports previous research suggesting that women are more likely than men to 412 provide hands-on care with instrumental activities of daily living, such as shopping and preparing 413 meals $\stackrel{30 z 4}{ }$. This has implications for family-focused care as women who adopt a care-giving role 414 experience more chronic health disorders, such as stress, anxiety and depression 10, 12, 15z0,25. Also, 415 when women try to manage the other person's condition, they may undermine their confidence to 416 control their own condition ${ }^{3126}$. Martire et al. ${ }^{26}$ conducted a meta-analysis of the effect of 417 psychosocial family interventions on people with a chronic illness and their relatives. The review did 418 not include interventions in people with diabetes but showed that family interventions have-positive 419 effects on patients' depression and on caregiving burden in relatives. Family interventions have the 420 potential to reduce caregiving burden and depression ${ }^{31}$. A systematic review and meta-analysis by

421 Armour et al. ${ }^{32}$ show that interventions which involve family members can lead to improved 422 diabetes knowledge and better controlled diabetes, and reduction in family conflicts. Future 423 interventions can utilise established behaviour change techniques ${ }^{33}$ to provide information about 424 diabetes, encourage communication within the family and set clear goals in terms of diet 425 management for the whole family. In addition, interventions could capitalise on dyadic coping 426 theory ${ }^{25}$ to account for different coping styles and optimise family cooperation. This may be 427 particularly important as the current study shows women and men may engage in different types of 428 dyadic coping. Supportive dyadic coping (often adopted by men) is a stronger predictor of 429 relationship satisfaction than delegated coping (often adopted by women) ${ }^{34}$. Family interventions 430 can help families discuss roles in relation to diet management and re-negotiate these roles by taking into account potential gender differences. However, interventions need to be sensitive to cultural 432 values when addressing gender roles and chronic illness. For example, Latinos are more traditionally 433 gender role oriented than other cultures and women are encouraged to provide emotional support 434 for their partners $\underline{3427}$. African American families may not talk about diabetes as they do not think it 435 should be discussed with family members $\stackrel{3528}{ }$. This could lead to the adoption of traditional gender 436 roles where people with type 2 diabetes and their relatives do not establish what their new role in 437 the family is. For example, women with diabetes adopt a multi-caregiving role, assuming family 438 members do not understand their needs and their husbands would not be supportive of diet change $439 \quad 36,3729,30$. However, this may not be the case as husbands are often willing to modify their behaviour 440 to support the wife's dietary needs ${ }^{307}$. Having culture-sensitive interventions is particularly 441 important in places where ethnic minority groups live. For example, in Scotland the percentage of 
ethnic minority groups varies from $6 \%$ to $12 \%$ in different council areas ${ }^{38}$ so a population-wide approach to diabetes management may not be suitable for these groups.

444 The study also has implications for direct provision of diabetes-related care. It shows that the 445 experiences of diet management in response to type 2 diabetes are not limited to the patient, so 446 patients can be encouraged to bring relatives to their diabetes appointments. Currently, in the UK 447 explanations about what to expect at diabetes appointments do not specify whether the patient 448 could bring a relative 39,40 . Attending a diabetes appointment together may provide a platform for 449 family discussion about the best way to manage dietary needs.

\section{Study limitations}

452 The current study has several limitations that should be considered. Sampling bias cannot be 453 excluded as participants who took part in the interviews contacted the researcher so it is not clear 454 whether people who volunteer to take part, have different characteristics from people who are 455 randomly chosen. In addition, all participants were white and living in the UK so the findings are not 456 transferable generalisable to other countries-or cultures. A recent study in 5 European countries 457 shows that gender differences in relation to diet management may be particularly evident in Spain 458 and Greece ${ }^{41}$. The authors suggest that in countries with particularly strong family structures, 459 women take responsibility for diet management. The role of culture in relation to gender roles 460 should be further investigated in future studies. Another limitation is the fact that not all interviews 461 included a person with type 2 diabetes and a relative from the same family and that the form of the 462 interviews was not consistent (individual vs family interview). More work is needed to uncover 463 different perceptions of roles in relation to diet and type 2 diabetes among family members. Finally, 464 the number of male relatives was low and this should be taken into consideration when interpreting 465 the study findings.

\section{Conclusion}

467 The current study suggests that women (whether with type 2 diabetes or relatives) may be more 468 likely to prioritise the needs of their family and take an active role in relation to diet management. 469 This is consistent with previous findings on gender and diet management in diabetes. The study 470 builds on previous work by showing that traditional gender roles, where women are responsible for 471 food preparation, may be still prevalent in the UK. Family-based interventions should focus on the 472 role of gender when adapting to chronic illness. While the results in this paper are drawn from 
473 secondary analysis, they provide meaningful contribution to existing literature on gender and diet 474 management in relation to type 2 diabetes.

\section{References}

$476{ }^{1}$ Wermeling, PR., Gorter, KJ., van Stel, HF. \& Rutten, GE. (2012). Both cardiovascular and non-

477 cardiovascular comorbidity are related to health status in well-controlled type 2 diabetes patients: A cross-sectional analysis. Cardiovascular Diabetology, 11.

479

4802 Diabetes UK (2019). Eating well with diabetes. Available from https://www.diabetes.org.uk/guide481 to-diabetes/enjoy-food/eating-with-diabetes Accessed 23.07.2019

482

${ }^{3}$ Franks, MM., Sahin, ZS., Seidel, AJ., Shields, CG, Oates, SK. \& Boushey, CJ. (2012). Table for Two: 484 Diabetes Distress and Diet-Related Interactions of Married Patients With Diabetes and Their 485 Spouses. Families, Systems \& Health, 30 (2), 154-165.

486

${ }^{4}$ Wen, LK., Shepherd, MD. \& Parchman, ML. (2004). Family Support, Diet, and Exercise Among Older 488 Mexican Americans With Type 2 Diabetes. The Diabetes Educator, 30 (6), 980-993. 489 $490 \quad{ }^{5}$ Gallant, M. (2003). The Influence of Social Support on Chronic Illness Self-Management: A Review 491 and Directions for Research. Health Education \& Behavior, 30 (2), 170-195.

492

$493{ }^{6}$ Revenson, T., Abraído-Lanza, Ana., Majerovitz, D. \& Jordan, C. (2005). Couples Coping With Chronic 494 Illness: What's Gender Got to Do With It? In T. Revenson, K. Kayser, G. Bodenmann (Eds) 495 Couples coping with stress: Emerging perspectives on dyadic coping (pp. 137-156). Washington, DC, 496 US: American Psychological Association.

497

$498{ }^{7}$ Bianchi, S. M., Sayer, L. C., Milkie, M. A. \& Robinson, J.P. (2012). Housework: Who Did, Does or Will 499 Do It, and How Much Does It Matter? Social Forces, 91, 55-63.

500

$501{ }^{8}$ Spitze, G. \& Ward, R. (2000). Gender, Marriage, and Expectations for Personal Care. Research on 502 aging, 22, 451-469.

503

$504{ }^{9}$ Maclean, H. (1991). Patterns of diet related self-care in diabetes. Social Sciences and Medicine, 32 505 (6), 689-696. 
506

$507{ }^{10} \mathrm{Li}, \mathrm{J}$, Drury, V. \& Taylor, B. (2014). Systematic review of the experience of older women living and 508 coping with type 2 diabetes. International Journal of Nursing Practice, 20, 126-134.

509

510

${ }^{11}$ Mathew, R., Gucciardi, E., Del Melo, M. \& Barata, P. (2012). Self-management experiences among 511 men and women with type 2 diabetes mellitus: a qualitative analysis. BMC Family Practice, 13.

512

${ }^{12}$ Hara, Y., Hisatomi, M., Ito, H., Nakao, M., Tsuboi, K. \& Ishihara, Y. (2014). Effects of gender, age, 514 family support, and treatment on perceived stress and coping of patients with type 2 diabetes mellitus. BioPsychoSocial Medicine, 8 (16).

516

${ }^{13}$ Wexler, DJ., Grant, RW., Meigs, JB., Nathan, DM. \& Cagliero, E. (2005). Sex disparities in treatment 518 of cardiac risk factors in patients with type 2 diabetes. Diabetes Care, 28, 514-520.

${ }^{14}$ Tuomilehto, J., Rastenyte, D., Jousilahti, P., Sarti, C \& Vartiainen. (1996). Diabetes mellitus as a risk 521 factor for death from stroke. Prospective study of the middle-ages Finnish population. Stroke, 27, $522 \quad 210-215$.

523

${ }^{15}$ Bédard, M., Kuzik, R., Chambers, L., Molloy, DW., Dubois, S., \& Lever, JA. (2005). Understanding burden differences between men and women caregivers: the contribution of care-recipient problem behaviors. International Psychogeriatrics, 17 (1), 99-118.

${ }^{16}$ Fort, MP., Castro, M., Peña, L., Hernández, SHL., Camacho, GA., Ramírez-Zeam, M. \& Martínez, H. (2015). Opportunities for involving men and families in chronic disease management: a qualitative study from Chiapas, Mexico. BMC Family Practice, 15.

${ }^{17}$ Ansari, RM., Hosseinzadeh, H., Harris, M. \& Zwar, N. (2019). Self-management experiences among middle-aged population of rural area of Pakistan with type 2 diabetes: A qualitative analysis. Clinical Epidemiology and Global Health, 7, 177-183.

${ }^{18}$ Samuel-Hodge, CD., Headen, SW., Skelly, AH., Ingram, AF., Keyserling, TC., Jackson, EJ. Ammerman, 537 AS. \& Elasy, TA. (2000). Influences on day-to-day self-management of type 2 diabetes among African538 American women. Spirituality, the multi-caregiver role, and other social context factors. Diabetes 539 Care, 23, 928-933. 
$541{ }^{19}$ Curtice, J., Clery, E., Perry, J., Phillips M. and Rahim, N. (eds.) (2019), British Social Attitudes: The

36th Report, London: The National Centre for Social Research

543

${ }^{20}$ Scottish Government (2019). Scottish Index of Multiple Deprivation. Available from

http://www.gov.scot/Topics/Statistics/SIMD Accessed 21.07.2019

546

${ }^{21}$ Spencer, L., Ritchie, J., Ormston, R., O’Connor, W. \& Barnard, M. (2014). Analysis: Principles and processes. In J. Ritchie, J. Lewis, C. Nicholls, R. Ormston (Eds) Qualitative research practice. A guide for Social Science students and researchers. SAGE Publications.

550

55122 Lacey, A. \& Luff, D. (2007). Qualitative data analysis. The NIHR RDS for the East Midlands /

552 Yorkshire \& the Humber.

553

$554{ }^{23}$ Beverly, E.A. \& Wray, L. A. (2010). The role of collective efficacy in exercise adherence: a

555 qualitative study of spousal support and Type 2 diabetes management. Health Education Research, $55625(2), 211-223$.

557

${ }^{24}$ Berg, CA. \& Upchurch, R. (2007). Developmental-Contextual Model of Couples Coping With

Chronic Illness Across the Adult Life Span. Psychological Bulletin, 133 (6), 920-954.

560

${ }^{25}$ Bodenmann, G. (2005). Dyadic coping and its significance for marital functioning. In T. Revenson,

K. Kayser, \& G. Bodenmann (Eds.), Couples coping with stress: Emerging perspectives on dyadic coping (pp. 33 - 50). Washington, DC: American Psychological Association.

${ }^{26}$ del Rio-Lozano, M., Garcia-Calvente, Mdel M., Marcos-Marcos, J., Entrena-Durán, F., MarotoNavarro, G. (2013). Gender Identity in Informal Care: Impact on Health in Spanish Caregivers. Qualitative Health Research, 23 (11), 1506-1520.

568

27 Bourdieu, P. (1998). Masculine domination. Stanford: Stanford University of Press.

570 Carmichael, F. \& Charles, S. (2003). The opportunity costs of informal care: does gender matter?

571 Journal of Health Economics, 22, 781-803. 
$573{ }^{28}$ Carmichael, F. \& Charles, S. (2003). The opportunity costs of informal care: does gender matter?

574 Journal of Health Economics, 22, 781-803.

575

$576{ }^{29}$ Figueiredo, D., Jacome, C., Gabriel, R., Marques, A. (2016). Family care in chronic obstructive 577 pulmonary disease: what happens when the carer is a man? Scandinavian Journal of Caring Sciences, $578 \quad 30,721-730$.

579

$580{ }^{30}$ Navaie-Waliser, M., Spriggs, A., \& Feldman, P. (2002). Informal caregiving. Differential experiences 581 by gender. Medical Care, 40, 1249-1259.

582

$583{ }^{31}$ Martire, LM., Lustig, AP., Schulz, R., Miller, G., Helgeson, VS. (2004). Is it beneficial to involve a 584 family member? A meta-analysis of psychosocial interventions for chronic illness. Health Psychology, $58523(6), 599-611$. 586 $587 \quad{ }^{32}$ Armour, TA., Norris, SL., Jack Jr, L., Zhang, X. \& Fisher, L. (2005). The effectiveness of family 588 interventions in people with diabetes mellitus: a systematic review. Diabetic Medicine, 22, 12955891305.

590

59133 Michie, S., Richardson, M., Johnston, M., Abraham, C., Francis, J., Hardeman, W., Eccles, M. P., 592 Cane, J. and Wood, C. E. (2013). The Behavior Change Technique Taxonomy (v1) of 93 Hierarchically 593 Clustered Techniques: Building an International Consensus for the Reporting of Behavior Change 594 Interventions. Annals of Behavioral Medicine, 46, pp. 81-95.

595

$596{ }^{34}$ Falconier, M. (2013). Traditional gender role orientation and dyadic coping in immigrant Latino 597 couples: Effects on couple functioning. Family Relations, 62, 269-283.

598

$599{ }^{35}$ Siddiqul, MA., Khan, MF. \& Carline, TE. (2013). Gender differences in living with diabetes mellitus. 600 Materia Socio Medica, 25(2), 140-142.

601

$602{ }^{36}$ Carter-Edwards, L., Skelly, AH., Cagle, CS. \& Appel, SJ. (2004). "They care but don't understand": 603 Family support of African American women with type 2 diabetes. The Diabetes Educator, 30 (3), 493 604501. 
605

606

607

608

609

610

611

612

613

614

615

616

617

618

619

620

621

622

623

624

${ }^{37}$ Van Boemal, GB. \& Paul, P. (1999). Effects of adherence to traditional female sex roles on

compliance with diabetic regimens. Journal of visual impairment and blindness, 93(1), 432-439.

${ }^{38}$ National Records of Scotland (2018). Scotland's census 2011: Ethnicity, Identity, Language and

Religion. Available from https://www.scotlandscensus.gov.uk/ethnicity-identity-language-and-

religion Accessed 23.07.2019

${ }^{39} \mathrm{NHS}$ (2019). Going for regular check-ups: Type 2 diabetes. Available from

https://www.nhs.uk/conditions/type-2-diabetes/going-regular-check-ups/_Accessed 23.07.2019

${ }^{40}$ Diabetes UK (2019). Diabetes Clinics. Available from https://www.diabetes.org.uk/guide-to-

diabetes/young-adults/diabetes-clinics_Accessed 23.07.2019

${ }^{41}$ Knutsen, IR., Foss, IC., Todorova, E., Roukova, P., Kennedy, A., Portillo, MC., Regaira, E. et al. (2015). Negotiating diet in networks: a cross-European study of experiences of managing type 2 diabetes. Qualitative Health Research, 1-12.

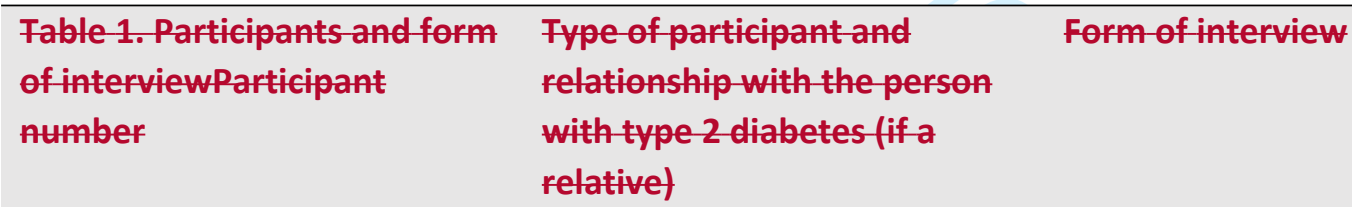

H1R1 Relative, mother

Relative only, interviewed alone

\begin{tabular}{lll}
\hline 12R2 & $\begin{array}{l}\text { Relative, daughter } \\
\text { Relative, daughter }\end{array}$ & $\begin{array}{l}\text { Interviewed together with } \\
\text { sister, mother and father } \\
(12 \mathrm{R} 3,12 \mathrm{R} 4,12 \mathrm{P} 1)\end{array}$ \\
\hline 12R3 & $\begin{array}{l}\text { Interviewed together with } \\
\text { sister, mother and father } \\
(12 \mathrm{R} 2,12 \mathrm{R} 4,12 \mathrm{P} 1)\end{array}$ \\
& Relative, wife & $\begin{array}{l}\text { Interviewed together with } \\
\text { daughters and husband (12R2, } \\
\text { 12R4 }\end{array}$ \\
& 12R3,12P1)
\end{tabular}




\begin{tabular}{|c|c|c|}
\hline 13R5 & Relative, wife & $\begin{array}{l}\text { Interviewed together with } \\
\text { husband }\left(13 P_{2}\right)\end{array}$ \\
\hline 15R6 & Relative, daughter & $\begin{array}{l}\text { Relative only, interviewed } \\
\text { alone }\end{array}$ \\
\hline 16R7 & Relative, wife & $\begin{array}{l}\text { Interviewed together with } \\
\text { husband (16P4) }\end{array}$ \\
\hline 18R8 & Relative, husband & $\begin{array}{l}\text { Interviewed separately from } \\
\text { wife (I4P3) }\end{array}$ \\
\hline 19R9 & Relative, daughter & $\begin{array}{l}\text { Relative only, interviewed } \\
\text { alone }\end{array}$ \\
\hline H1R10 & Relative, daughter & $\begin{array}{l}\text { Interviewed separately from } \\
\text { mother (I10P6) }\end{array}$ \\
\hline H12R11 & Relative, son & $\begin{array}{l}\text { Relative only, interviewed } \\
\text { alone }\end{array}$ \\
\hline H13R12 & Relative, husband & $\begin{array}{l}\text { Interviewed together wife } \\
\text { (113P7) }\end{array}$ \\
\hline H16R13 & Relative, daughter & $\begin{array}{l}\text { Interviewed separately from } \\
\text { parents (16P4, I6R7) }\end{array}$ \\
\hline $12 P 1$ & Person with type 2 diabetes & $\begin{array}{l}\text { Interviewed together with } \\
\text { daughters and wife (12R2, } \\
\text { 12R3, 12R4) }\end{array}$ \\
\hline $13 P 2$ & Person with type 2 diabetes & $\begin{array}{l}\text { Interviewed together with wife } \\
\text { (13R5) }\end{array}$ \\
\hline $14 \mathrm{P3}$ & Person with type 2 diabetes & $\begin{array}{l}\text { Interviewed separately from } \\
\text { husband (18R8) }\end{array}$ \\
\hline $16 P 4$ & Person with type 2 diabetes & $\begin{array}{l}\text { Interviewed together with wife } \\
\text { (H6R7) }\end{array}$ \\
\hline $17 P 5$ & Person with type 2 diabetes & $\begin{array}{l}\text { Person with type } 2 \text { diabetes } \\
\text { only, interviewed alone }\end{array}$ \\
\hline 110P6 & Person with type 2 diabetes & $\begin{array}{l}\text { Interviewed separately from } \\
\text { daughter (I11R10) }\end{array}$ \\
\hline $113 P 7$ & Person with type 2 diabetes & $\begin{array}{l}\text { Interviewed together with } \\
\text { daughter }(113 R 12)\end{array}$ \\
\hline 14P8 & Person with type 2 diabetes & $\begin{array}{l}\text { Person with type } 2 \text { diabetes } \\
\text { only, interviewed alone }\end{array}$ \\
\hline 115pg & Person with type 2 diabetes & $\begin{array}{l}\text { Person with type } 2 \text { diabetes } \\
\text { only, interviewed alone }\end{array}$ \\
\hline
\end{tabular}




$\begin{array}{ll}17 \text { Person with type 2 diabetes } & \begin{array}{l}\text { Person with type 2 diabetes } \\ \text { only, interviewed alone }\end{array}\end{array}$

Table 12. Participants' characteristics

\begin{tabular}{|c|c|c|}
\hline & People with type 2 diabetes & Relatives \\
\hline № & 10 & 13 \\
\hline Duration of type 2 diabetes & $\begin{array}{l}\text { Range: } 3 \text { weeks - } 18 \text { months } \\
\text { Mean: } 7.9 \text { months } \\
\text { Median: } 6.5 \text { months }\end{array}$ & - \\
\hline Route to diagnosis & $\begin{array}{l}5 \text { presenting GP with } \\
\text { symptoms; } 3 \text { periodic } \\
\text { screening; } 1 \text { visit GP for other } \\
\text { reasons; } 1 \text { after gestational } \\
\text { diabetes }\end{array}$ & - \\
\hline $\begin{array}{l}\text { Relationships with the person } \\
\text { with type } 2 \text { diabetes }\end{array}$ & - & $\begin{array}{l}6 \text { daughters, } 3 \text { wives, } 2 \\
\text { husbands, } 1 \text { son, } 1 \text { mother. } \\
6 \text { share genetics but live apart } \\
\text { from the person with type } 2 \\
\text { diabetes } \\
2 \text { share genetics and live } \\
\text { together } \\
5 \text { do not share genetics and } \\
\text { live together }\end{array}$ \\
\hline Gender & 5 male, 5 female & 10 female, 3 male \\
\hline Age & $\begin{array}{l}\text { Range: } 37-71 \text { years } \\
\text { Mean: } 53.6 \text { years } \\
\text { Median: } 51 \text { years }\end{array}$ & $\begin{array}{l}\text { Range: } 18-68 \text { years } \\
\text { Mean: } 41.17 \text { years } \\
\text { Median: } 45.5 \text { years }\end{array}$ \\
\hline $\begin{array}{l}\text { SIMD (Scottish Index of } \\
\text { Multiple Deprivation) }\end{array}$ & $\begin{array}{l}\text { Range: } 2-10 \\
\text { Mean: } 5.7 \\
\text { Median: } 6\end{array}$ & $\begin{array}{l}\text { Range: } 2-10 \\
\text { Mean: } 6.92 \\
\text { Median: } 6\end{array}$ \\
\hline
\end{tabular}




\begin{tabular}{|c|c|c|}
\hline Education & $\begin{array}{l}9 \text { had education after high } \\
\text { school ( } 2 \text { PhD, } 1 \text { MSc, } 2 \\
\text { BAs/BSc, } 1 \text { one year at } \\
\text { university, } 1 \text { Diploma, } 1 \text { Police } \\
\text { promotion exam, } 1 \text { HNC, } \\
2 \text { current students) }\end{array}$ & $\begin{array}{l}9 \text { had education after high } \\
\text { school ( } 3 \text { PhD, } 1 \text { MSc, } 2 \\
\text { BAs/BSc, } 2 \text { college, } 1 \text { SHND, } \\
3 \text { current students) }\end{array}$ \\
\hline Employment & $\begin{array}{l}4 \text { full-time, } 3 \text { retired, } 2 \\
\text { unemployed, } 1 \text { part-time }\end{array}$ & $\begin{array}{l}4 \text { full-time, } 4 \text { part-time, } 2 \\
\text { unemployed, } 1 \text { self-employed, } \\
1 \text { retired, } 1 \text { other }\end{array}$ \\
\hline Relationship status & 8 in a relationship, 2 single & 12 in a relationship, 1 single \\
\hline
\end{tabular}

\begin{tabular}{lll}
\hline Family history of diabetes & 5 yes, 5 no & 8 yes, 5 no \\
& $\begin{array}{l}\text { Number of relatives with } \\
\text { diabetes: } 1-4\end{array}$ & $\begin{array}{l}\text { Number of relatives with } \\
\text { diabetes: } 1-4\end{array}$ \\
\hline $\begin{array}{l}\text { How they heard about the } \\
\text { study }\end{array}$ & $\begin{array}{l}5 \text { word of mouth (relative who } \\
\text { took part or someone who saw } \\
\text { advert) }\end{array}$ & $\begin{array}{l}7 \text { word of mouth (through } \\
\text { someone who took part or } \\
\text { someone who saw advert) }\end{array}$ \\
& $\begin{array}{l}2 \text { University of Stirling portal } \\
1 \text { Diabetes UK newsletter }\end{array}$ & $\begin{array}{l}\text { 2 University of Stirling email } \\
\text { advert }\end{array}$ \\
& $\begin{array}{l}1 \text { Poster at a community } \\
\text { centre }\end{array}$ & 2 University of Stirling portal \\
& $\begin{array}{l}1 \text { Local Diabetes support group } \\
\text { social media page }\end{array}$ & \\
\hline
\end{tabular}

632 Table 2. Participants and form of interview

\begin{tabular}{|c|c|}
\hline Form of interview & $\begin{array}{l}\text { Participants' characteristics in the context of } \\
\text { the study }\end{array}$ \\
\hline Interviewed together & $\begin{array}{l}\text { A man with type } 2 \text { diabetes (I2P } 1,55 \text { years old, } \\
6 \text { months since diagnosis), his wife }(12 \mathrm{R} 3,54 \\
\text { years old) and daughters (I2R } 2,23 \text { years old } \\
\text { and I2R4, } 20 \text { years old). } \\
\text { A man with type } 2 \text { diabetes (I3P } 2,47 \text { years old, } \\
2 \text { months since diagnosis) and his wife (I3R5, } 46 \\
\text { years old). }\end{array}$ \\
\hline
\end{tabular}




\begin{tabular}{|c|c|}
\hline & $\begin{array}{l}\text { A man with type } 2 \text { diabetes ( } 16 \mathrm{P} 4,70 \text { years old, } \\
3 \text { months since diagnosis) and his wife (I6R7,60 } \\
\text { years old). }\end{array}$ \\
\hline Interviewed separately & $\begin{array}{l}\text { A woman with type } 2 \text { diabetes (I4P3, } 39 \text { years } \\
\text { old, } 7 \text { months since diagnosis) and her husband } \\
\text { (I8R8, } 47 \text { years old). } \\
\frac{\text { A woman with type } 2 \text { diabetes (I10P6, } 65 \text { years }}{\text { old, } 6 \text { months since diagnosis) and her daughter }} \\
\text { (I11R10,29 years old). } \\
\frac{\text { A woman with type } 2 \text { diabetes (I13P7, } 60 \text { years }}{\text { old, } 10 \text { months since diagnosis) and her }} \\
\text { husband (I13R12, } 60 \text { years old). } \\
\frac{\text { A daughter of a man with type } 2 \text { diabetes }}{\text { (I16R13, } 45 \text { years old) and her parents (I6P4, }} \\
\text { I6R7). }\end{array}$ \\
\hline Interviewed alone (relative did not take part) & $\begin{array}{l}\text { A woman with type } 2 \text { diabetes (I7P5, } 45 \text { years } \\
\text { old, } 3 \text { weeks since diagnosis). } \\
\text { A woman with type } 2 \text { diabetes (I14P8, } 47 \text { years } \\
\text { old, } 18 \text { months since diagnosis). } \\
\text { A man with type } 2 \text { diabetes (I15P9, } 37 \text { years } \\
\text { old, } 8 \text { months since diagnosis). } \\
\text { A man with type } 2 \text { diabetes (I17P10, } 71 \text { years } \\
\text { old, } 18 \text { months since diagnosis). } \\
\text { A mother of a man with type } 2 \text { diabetes (I1R } 1, \\
68 \text { years old, son diagnoses in the past } 6 \\
\text { months). } \\
\text { A daughter of a man with type } 2 \text { diabetes (I5R6, } \\
18 \text { years old, father diagnosed } 8 \text { months ago). } \\
\text { A daughter of a man with type } 2 \text { diabetes (I9R9, } \\
\text { age not reported, father diagnosed } 6 \text { weeks } \\
\text { ago). } \\
\frac{\text { A son of a man with type } 2 \text { diabetes (I12R11, } 24}{\text { years old, father diagnosed } 11 \text { months ago). }}\end{array}$ \\
\hline
\end{tabular}




\section{Gender and diet management in type 2 diabetes}

\section{Abstract}

3 Introduction: Type 2 diabetes is a chronic health condition that requires ongoing self-management.

4 This often includes changes in diet, which may be open to influences from relatives. Family support

5 in terms of diet may be linked with gender and the assumption that meal preparation is a

6 traditionally female activity. This article looks at the role of gender in diet management in people

$7 \quad$ with type 2 diabetes and their relatives.

8 Methods: Seventeen semi-structured interviews were conducted with 23 participants (10 people

9 with type 2 diabetes, 13 relatives of people with type 2 diabetes) in Scotland, UK. The aim was to

10 uncover changes people have made to their diet following diagnosis of type 2 diabetes in oneself or

11 a family member. Data were analysed using Framework Approach.

Findings: Female relatives were more likely to manage the patient's diet while male relatives provided support but were less likely to monitor the person's diet. Female patients may prioritise the needs of their family while male patients are more likely to rely on their female relatives in terms of diet management.

Discussion: The study findings have implications for family-based interventions as gender may play a crucial role in the management of type 2 diabetes.

Key words: type 2 diabetes, diet management, family, gender, interviews.

\section{Introduction}

Type 2 diabetes is a chronic health condition that requires ongoing self-management in order to minimise negative health consequences such as developing comorbidities ${ }^{1}$. People with type 2 diabetes are advised to monitor their diet in order to maintain certain blood-glucose levels ${ }^{2}$. A "healthy and balanced" diet that is rich in fibre and low in salt and sugar is recommended². Diabetes self-management can be facilitated by relatives and partners who can provide advice and support, and assist with daily activities ${ }^{3,4}$. This is particularly relevant to diet management, which as a shared activity, may be more open to influences from family members than other behaviours ${ }^{4,5}$. However, family support in terms of diet may be linked with gender and the assumption that meal preparation is a traditionally female activity ${ }^{6,7}$. This may be particularly relevant to middle-aged and older women who are less likely to rely on spouses with everyday activities ${ }^{8}$. Previous research in diabetes suggests specific gender differences in relation to diet management. For example, Maclean ${ }^{9}$ found that married men with type 1 diabetes were at "an advantage" because in almost all cases of their 
sample the wives prepared meals, which conformed to the prescribed diet. Women with type 1 diabetes in Maclean's ${ }^{9}$ study, however, often had to balance their personal needs with the food needs of their family. More recent research shows a similar pattern. A systematic review by Li et al. ${ }^{10}$ found that women with type 2 diabetes often prioritise the needs of their family and adopt multicare-giving responsibilities. They often subjugate their own needs for the needs of their family members and cook separate meals for themselves ${ }^{11}$. As a result, women show low dependence on their spouses and do not identify their spouse as a source of support ${ }^{10-12}$. On the other hand, men with type 2 diabetes are more likely to be dependent on their spouses in relation to diet management and identify their wife as a main source of support ${ }^{11,12}$. This is particularly problematic in respect to morbidity and mortality: women with type 2 diabetes are at increased risk of death from cardiovascular disease and stroke, compared to men ${ }^{13,14}$. In addition, women with caregiving responsibilities may experience higher levels of perceived burden which can lead to poor physical and mental health ${ }^{15}$. Traditional gender role orientation in relation to diet management may be particularly prominent in certain cultures. For example, in a Mexican sample, women were viewed as "food preparers" so they took the responsibility for managing a patient's diet ${ }^{16}$. Similarly, a qualitative study conducted in Pakistan showed that men view diet change as a matter for wives whose job it is to prepare the right food ${ }^{17}$. In an African-American sample, traditional gender roles extended to daughters, who were the main providers of diabetes-related care, including diet management ${ }^{18}$.

In the UK, there has been a decline in traditional gender role perceptions with $72 \%$ of respondents in 2019 disagreeing that women should be viewed as homemakers ${ }^{19}$. However, there is still a gap in understanding how gender plays a role in diet management following diagnosis of type 2 diabetes in oneself or a family member. In addition, the majority of previous research has explored this from the perspective of the person with type 2 diabetes. The experiences of family members and the role gender plays in providing support for someone with type 2 diabetes are seldom the focus of research. A better understanding of traditional gender roles in diet management can provide insight into ways to improve self-care in patients and provide support for relatives.

The objective of this article is to describe the role of gender in diet management in response to a recent diagnosis of type 2 diabetes. The study builds on previous research by presenting the views of both patients with type 2 diabetes and relatives of such patients.

\section{Methods}

Ethical approval for this study was granted by the University of Stirling, School of Health Sciences ethics committee (SREC 15/16, Paper No. 37, version 1). 
This was a qualitative study, conducted in Scotland (UK), which explored the way people respond to and cope with diagnosis of type 2 diabetes in oneself or in a family member. The aim was to interview people who had recently been diagnosed with type 2 diabetes and at least one of their non-diabetic family members in order to uncover people's shared experiences of diabetes. A recent diagnosis in oneself or a family member decreased the risk of recall bias and optimised the chance of participants recollecting specific changes that occurred as a result of the diagnosis. This article presents the findings related to diet management.

\section{Recruitment}

Recruitment was carried out through community outreach in Forth Valley, Scotland. Posters and flyers, explaining the study, were distributed at 109 community locations, such as community centres, libraries, charity shops, bowling clubs, golf clubs, local post office branches and the University of Stirling. In addition, Diabetes UK advertised the study on their website, newsletter and social media pages. The study was also advertised by word of mouth.

People who expressed interest were screened for eligibility on the basis of the following criteria: 1 ) over the age of 18 years; 2) able to speak and write in English; 3) a recent diagnosis of type 2 diabetes in oneself or a family member. As type 2 diabetes is a chronic condition, people's perception of what constitutes a recent diagnosis may differ so a specific timeframe was not used. If a participant was eligible to take part, they were asked to nominate one non-diabetic family member who might be willing to take part in the study (or nominate the relative with diabetes if it was the family member who got in touch). The participant was then asked to provide their family member with the study flyer and the researcher's contact details.

\section{Data collection}

Semi-structured face to face or phone interviews were conducted with people with type 2 diabetes and relatives of people with type 2 diabetes. First, participants completed a brief questionnaire that collected information about duration of type 2 diabetes, route to diagnosis, relationship with the person with type 2 diabetes (for relatives), gender, age, highest education, employment status, relationship status and postcode to enable calculation of the Scottish Index of Multiple Deprivation (SIMD) or full address if the participant wanted to receive information about study findings. The SIMD is used to identify areas of multiple deprivation in Scotland by ranking small areas from most deprived (ranked 1) to least deprived (ranked 10) ${ }^{13}$. The interview aimed to uncover changes in participants' lives since the diagnosis of type 2 diabetes in themselves or in a family member. The topic areas included psychological changes in perceptions of diabetes severity and risk of complications (or developing type 2 diabetes in relatives), behaviour changes in relation to physical 
activity, diet and responsibilities, communication about type 2 diabetes and suggestions for diabetes service improvements and intervention design. Example questions in relation to diet included: "What changes in relation to diet have you made since the diagnosis?", "What barriers have you experienced?", "Tell me more about your family and what they do in relation to your diet?". The interviews were semi-structured so questions varied depending on the participant's response. Probes included: "How easy was it to change your diet?", "Do you and your partner do anything differently together?", "Have your responsibilities in the house changed?".

An important consideration for the study was whether to interview members of the same family together or separately. Joint interviews are useful when the interviews seek to explore the way people collectively cope with illness. Individual interviews are useful when each individual's perspective is sought. Although the initial aim was to interview people together, not all participants could agree on a suitable time, so some members of the same family were interviewed separately. In some cases, the interviews also included only one member of a family as other family members did not agree to take part. The decision not to exclude people whose family members were unable to take part was influenced by three reasons 1 ) the study did not aim to explore discrepancies in the views of men and women from the same family; 2 ) to reduce the risk of coercion from family members who want to take part and 3) practical considerations, such as time and money, as this study was part of a PhD project. Although a family interview would shed light into the way people interact when talking about diet management, individual perspectives are important as in some cases people may be more open if family members are not present.

The interviews were conducted by a female researcher with training and experience in collecting qualitative data (EDD). Data collection continued until data saturation was reached. We conceptualised data saturation in terms of the study target group and quality and quantity of information. The study participants represented a group with specific characteristics (i.e. recent diagnosis of type 2 diabetes in oneself or a family member, living in the UK). Participants openly talked about their experience, which enabled the researcher to gain sufficient information and notice similarities (or differences) in experiences throughout the data collection process. In order to avoid data redundancy, saturation was deemed to have been achieved when no new data emerged.

\section{Data analysis}

The interviews were audio-recorded, transcribed verbatim and checked against the recordings for accuracy. All information was anonymised and participants were given study numbers. The file linking the study numbers with participants' details was kept separately from the recordings and 
131 transcripts. Data were analysed using Framework Approach, which is based on the assumption that 132 the researcher stays close to the original data in order to "capture, portray and explain the social 133 worlds of the people under study" (p.279) ${ }^{14}$. This approach was chosen because it is better adapted 134 to research that has specific questions and a priori issues that need to be explored and as it helps to 135 facilitate case analysis. In addition, it provides systematic and clear stages to the analytic process, 136 thus allowing people to see the stages, by which the results are obtained ${ }^{15}$. This transparency 137 ensures trustworthiness of data, especially in terms of credibility and confirmability. In addition, 138 having a clear process increases study transferability and dependability making it easier for others to 139 explore the consistency of findings and compare them to other contexts and conditions. Analysis 140 followed the data analysis stages, suggested by Spencer et al. ${ }^{14}$, which include familiarisation, 141 constructing an initial framework, indexing and sorting, reviewing data extracts, data summaries, 142 developing categories, mapping linkages, and providing explanations and interpretations. The 143 interview questions were initially used to guide data analysis. During the developing categories 144 stage, while detecting elements initial themes had in common, it became apparent that participants' 145 responses in relation to diet management appeared to differ between men and women. This 146 enabled the identification of the themes presented in this article. Analysis was conducted by the 147 primary author. Another author with extensive experience in qualitative research (VS) reviewed the 148 data analysis stages to ensure that the final themes emerged from the data.

\section{Findings}

151 Forty two people showed interest in the study (22 people with type 2 diabetes, 20 relatives). Twenty three participants took part in 17 semi-structured interviews. Sample characteristics are presented in Table 1.

Insert Table 1 about here

156

Thirteen of the interviews were individual and four included the person with type 2 diabetes and their relative(s). Ten were people with type 2 diabetes and 13 were relatives of people with type 2 diabetes. Relationships included two families (father, mother, two daughters; father, mother, daughter); a mother-daughter dyad; and three couples. The remainder were either a person with type 2 diabetes or a relative whose family members were unable to take part. Details about the relationships between participants and how they were interviewed are presented in Table 2 . 
Interviews were conducted between November 2015 and March 2016 and took place in participants' homes $(N=6)$, private rooms at University of Stirling $(N=6)$, a local hotel $(N=1)$, a local library $(N=1)$ and a private office at a participant's workplace $(\mathrm{N}=1)$, and over the phone with the researcher in a private room ( $\mathrm{N}=2$ ). Interviews lasted between 25 and 85 minutes. Participants were given $f 10$ as reimbursement for participation.

\section{Insert Table 2 about here}

Data analysis yielded two themes addressed by both people with type 2 diabetes and their relatives: Women - taking responsibility for diet management, and Men - "going along" with the new diet.

\section{Women - taking responsibility for diet management}

Virtually all relatives of people with type 2 diabetes talked about supporting diabetes selfmanagement. However, compared to men, women more often talked about a desire to manage the person's condition, take an active role in trying to prescribe a specific diet regimen and ensure the person with type 2 diabetes adheres to it.

"The female always has a bit of a problem because they usually stereotypically are the ones responsible for shopping and cooking food, so you've got to manage this condition for them, at least for one meal a day." R5, wife of a man with type 2 diabetes

Female relatives of people with type 2 diabetes talked about searching for information on dietary management by buying and borrowing books, and searching on the internet. In line with such information, they made changes to the food they cooked:

"Just trying to research food for dad, trying to make him better meals. Make him different sandwiches all the time at work." R4, daughter, lives with father with type 2 diabetes

This was not necessarily a change in roles as in both cases the women were responsible for meal preparation before the diagnosis of type 2 diabetes. However, they perceived it to be their role to change the meals to align with diabetes-related recommendations. This perceived need to manage the person's diet often led to additional responsibilities and affected other aspects of the women's lives:

"I make sure what he [father] has every day: "you are not allowed to eat that anymore" so it's quite hard to have to balance my university with all this watching his diet as well as mine, and 
193

194

195

196

197

198

199

200

201

202

203

204

205

206

207

208

209

210

211

212

213

215

216

217

218

219

220

221

222

they're just jumbled up with each other." R6, daughter, lives apart from father with type 2 diabetes

In other cases, it presented a difficulty in managing the diet of other family members:

"Yeah, I try and buy less sweet things but for me, the dilemma is very difficult, because our daughter is underweight and doesn't eat very much at all and she is much more likely to eat biscuits and cakes and sweets than anything else, so it's trying to balance her need to have a high calorie [diet]." R5, wife of a man with type 2 diabetes

The perceived need to monitor the person's behaviour was described as "policing" where women felt they need to ensure the patients comply with the specific diabetes-related diet regimen:

"... so for me one of the changes is knowing what's supportive and what's not, so the challenge existing is trying to police and say "you can't do this and you can't do that, you know, do you really need to eat that or should you be eating that, you know" because it's not gonna help, you know, 'cause you can just eat it when I'm not there, if you wanted to, but I find it hard to resist the urge to interfere." R5, wife of a man with type 2 diabetes

"... think he eats sweet packets so that gives me a reason to shout at him for it." R6, daughter, lives apart from father with type 2 diabetes

The second quote comes from the daughter of a person with type 2 diabetes and suggests a form of role reversal where children tell parents what to do. Although it is perceived as expected for children to look after parents at a certain stage of life, type 2 diabetes appeared to be a trigger for this role reversal:

"I would say usually, growing up your dad looks after you, but I'm suddenly thinking I need to look more after my dad as well." R2, daughter, lives apart from father with type 2 diabetes

One woman with type 2 diabetes talked about the diagnosis as the moment when children may realise they need to look after their parents:

"...I suppose because I had the diagnosis and because of the potential for strokes and things like that, you can tell for the very first time they are thinking of me as someone who can die." P6, a woman with type 2 diabetes, lives alone

In some families, the roles before diagnosis did not align with traditional roles and assumptions where the wife does most of the cooking. However, diagnosis of type 2 diabetes in the husband appeared to affect this and change relationship balance: 
"I think probably the balance in our relationship has changed. I would probably see me having more of a caring role than I had before. And I think like [husband]. said, [husband] used to do all the cooking and the balance in that has changed." R7, wife of a man with type 2 diabetes "She [wife] likes caring for people, you know, she likes caring for me so in fact one thing, here you go, that's one thing that's changed, she does a lot more cooking than she used to (...) she is not a great cook but she is trying, she is doing a lot more of it to try and make things easier for me" P9, a man with type 2 diabetes, lives with family

Although in these cases, the men may have experienced diabetes-related symptoms that interfered with their ability to continue cooking, this was not reported by women with type 2 diabetes. Women with type 2 diabetes continued to perceive that it was their responsibility to prepare meals, which in some cases added additional diet-related responsibilities, such as cooking two meals:

"I'll sometimes cook whatever they [family members] want and I'll have something separate or I'll do myself something separate." P8, a woman with type 2 diabetes, lives with family

Women did not always live with the person with type 2 diabetes. In one case (see R6 earlier), the daughter phoned her father every day to monitor what he has eaten that day. In other cases, the likelihood of women taking an active role in the management of the person's diet appeared to be influenced by geographical closeness. Although not directly explored, it appeared that these women managed the patient's diet only on the occasions when they visited them:

"I am much less willing to offer him cakes or biscuits or anything like that... erm...I am much more focused on giving him salads." R1, mother, lives separate from son with type 2 diabetes

\section{Men - "going along" with the new diet}

Compared to the women in this sample, men provided support for their relatives with type 2 diabetes but were less likely to take responsibility for managing their relatives' diet. Men were understanding of the fact that their relative with type 2 diabetes needs to adopt diet changes and they expressed willingness to support them by complying with the new diet regimen. Men also provided advice and encouragement to their relative with type 2 diabetes. However, they made a clear distinction between themselves and their relatives by highlighting that the responsibility for diet management falls on the person with type 2 diabetes: 
2

\section{"I mean I understand that, you know, what [wife]'s got, you know, I am quite happy to go} along with it and if I need to pig out or something, I'm probably gonna do it." R12, husband of a woman with type 2 diabetes

"So I do try and get him to go out, like I always invite him for runs and stuff like that (...) He is very aware that it's his diagnosis and it's up to him to manage it himself" R11, son, lives together with father with type 2 diabetes

Sometimes, men believed that by complying with the new diet regimen, they have started eating more healthily:

"Yeah, as I say, she prepares the meals, so she prepares meals that are good so l eat more healthy because of what she is cooking." R8, husband of a woman with type 2 diabetes

However, this participant's perception differed from his wife's opinion:

"I make him be healthy but it's rubbish...he would just eat anything." P3, female with type 2 diabetes talking about her husband

This illustrates potential differences in the way men and women perceive making diet changes and providing support following diagnosis of type 2 diabetes. It further illustrates that women may take responsibility for managing the diet of the whole family by trying to "make" people eat healthy food. These participants were interviewed separately so the difference in perception could not be explored in more depth.

Men with type 2 diabetes also appeared to rely on their female relatives for diet management:

"She is telling me what to eat, l eat it." P4, male with type 2 diabetes, lives with wife

This man also appeared to avoid taking responsibility for his diabetes management and relying on his wife and other people to ensure he complies with the diet regimen:

"If I do something that's gonna make it [type 2 diabetes] worse, l'd hope somebody either the doctor or a nurse or [wife] would point out that I was doing it." P4, male with type 2 diabetes, lives with wife

The potential difference in perceived responsibility for and approach to diet management between men and women is illustrated below in a quote from a man who considered a hypothetical situation where his wife, instead of him, had type 2 diabetes:

"I would've sort of wanted to be more supportive but I wouldn't have got five textbooks and all that kind of stuff." P2, male with type 2 diabetes, lives with family 
284

There was only one man with type 2 diabetes in the current study who said his wife did not change her diet to support him in his diet management:

"I think initially I probably drove her quite mad with my weighing portions and so on, I think because she wasn't doing it. I think she found that a bit irritating but beyond that she was quite accommodating". P10, male with type 2 diabetes, lives with wife

\section{Discussion}

The findings in this article illuminate the role of gender in diet management for people with type 2 diabetes and their families. The study found that female relatives are more likely to take responsibility for ensuring the person with type 2 diabetes conforms to the new diet. Similarly, women with type 2 diabetes believed it is their responsibility to change their own diet, which sometimes resulted in adopting additional responsibilities. Men, whether patients or relatives, were more likely to comply with diet changes, initiated by women, rather than actively manage diet.

\section{Women - taking responsibility for diet management}

In this study, women talked about their desire to take an active role in diet management in response to type 2 diabetes in their relative. This is consistent with previous findings that women are more likely, compared to men, to assume responsibility for the management of their partner's diabetes ${ }^{23}$.

The behaviour exhibited by female relatives in the current sample can be described by using the dyadic perspective of coping 24,25 , according to which patient and partner interact with each other to mutually influence the adjustment process. Although the model of dyadic coping was developed in partners/spouses, it could apply to other family dyads, such as parent-offspring dyads. Women appear to engage in delegated dyadic coping, where they take over certain responsibilities to alleviate the burden from the person with type 2 diabetes ${ }^{25}$. Women were more likely to monitor other people's diet and engage in "policing", which in some cases resulted in a shift in relationship balance (women adopting new roles) and role reversal (children telling parents what to do). Similar patterns of behaviour in terms of family roles following diagnosis of diabetes have been observed before ${ }^{16,18}$. Samuel-Hodge et al. ${ }^{18}$ explored diabetes management in African-Americans and found that family members often engage in food policing. A potential explanation for women's increased likelihood to adopt a caregiving role is the suggestion that women internalise and take the caregiving role more seriously ${ }^{26}$. This could be rooted in historical and social practices. Bourdieu ${ }^{27}$ argues that traditional gender roles have been maintained through social construction and gender socialisation, so women are considered to be inherently more likely to be caregivers. This is further confirmed by recent findings that women may be viewed by their husbands as "food preparers"16,17. Bourdieu's ${ }^{27}$ 
suggestion also supports the finding that women with type 2 diabetes in the current study prioritised the needs of their family thus adopting additional responsibilities (for example by cooking two separate meals). Often, in families where men did the cooking, after their type 2 diabetes diagnosis women's role in the kitchen appeared to increase. However, when women were the ones diagnosed with type 2 diabetes, they continued to cook without men taking additional responsibilities in relation to food preparation.

Although not directly explored in this study, the likelihood of relatives to adopt a caring role may be influenced by geographical distance. According to Carmichael and Charles ${ }^{28}$ geographical distance is a type of a "non-economic" factor that influences people's decision to adopt a caring role. Some of the participants in the current study admitted that they thought more often about their relative with type 2 diabetes but having work and family obligations and living far away from their relative, interfered with their ability to provide support. However, female relatives talked about changing the meals they prepare when their relative with type 2 diabetes visits them.

\section{Men - "going along" with the new diet}

330 Men, in the current sample, often talking about relying on their relatives to make diet changes and

331 "going along" with these changes was perceived as supportive behaviour. This can be explained in 332 terms of supportive dyadic coping where men provided support, advice and encouragement ${ }^{25}$. This 333 is consistent with previous research that men with type 2 diabetes are more likely to depend on 334 their spouses ${ }^{11,12}$. Del Rio-Lozano et al. ${ }^{26}$ suggests that men have a more flexible approach to care 335 and do not identify with the caregiving role. This may put men at a position of advantage because 336 their wives prepare meals that conform to the prescribed $\operatorname{diet}^{9}$. Although the sample of male 337 relatives in the current study was small, the results showed that men provided support and advice to their relatives with type 2 diabetes but were less likely to feel responsible for monitoring the patient's diet. We were not able to explore differences in support provision between husbands and sons but previous research suggests that there is a difference between sons' and husbands' perception of caregiving ${ }^{29}$. Sons perceive a filial obligation to provide care for their mothers while husbands see caregiving as an extension of their marital role ${ }^{29}$.

\section{Implications}

345 The current study supports previous research suggesting that women are more likely than men to 346 provide hands-on care with instrumental activities of daily living, such as shopping and preparing 347 meals ${ }^{30}$. This has implications for family-focused care as women who adopt a care-giving role 348 experience more chronic health disorders, such as stress, anxiety and depression ${ }^{10,12,15}$. Also, when 
349

350

351

352

353

354

355

356

357

358

359

360

361

362

363

364

365

366

367

368

369

370

371

372

373

374

375

376

377

378

379

380

381

women try to manage the other person's condition, they may undermine their confidence to control their own condition ${ }^{31}$. Family interventions have the potential to reduce caregiving burden and depression ${ }^{31}$. A systematic review and meta-analysis by Armour et al. ${ }^{32}$ show that interventions which involve family members can lead to improved diabetes knowledge and better controlled diabetes, and reduction in family conflicts. Future interventions can utilise established behaviour change techniques ${ }^{33}$ to provide information about diabetes, encourage communication within the family and set clear goals in terms of diet management for the whole family. In addition, interventions could capitalise on dyadic coping theory ${ }^{25}$ to account for different coping styles and optimise family cooperation. This may be particularly important as the current study shows women and men may engage in different types of dyadic coping. Supportive dyadic coping (often adopted by men) is a stronger predictor of relationship satisfaction than delegated coping (often adopted by women $)^{34}$. Family interventions can help families discuss roles in relation to diet management and re-negotiate these roles by taking into account potential gender differences. However, interventions need to be sensitive to cultural values when addressing gender roles and chronic illness. For example, Latinos are more traditionally gender role oriented than other cultures and women are encouraged to provide emotional support for their partners ${ }^{34}$. African American families may not talk about diabetes as they do not think it should be discussed with family members ${ }^{35}$. This could lead to the adoption of traditional gender roles where people with type 2 diabetes and their relatives do not establish what their new role in the family is. For example, women with diabetes adopt a multi-caregiving role, assuming family members do not understand their needs and their husbands would not be supportive of diet change ${ }^{36,37}$. However, this may not be the case as husbands are often willing to modify their behaviour to support the wife's dietary needs ${ }^{37}$. Having culture-sensitive interventions is particularly important in places where ethnic minority groups live. For example, in Scotland the percentage of ethnic minority groups varies from $6 \%$ to $12 \%$ in different council areas ${ }^{38}$ so a population-wide approach to diabetes management may not be suitable for these groups.

The study also has implications for direct provision of diabetes-related care. It shows that the experiences of diet management in response to type 2 diabetes are not limited to the patient, so patients can be encouraged to bring relatives to their diabetes appointments. Currently, in the UK explanations about what to expect at diabetes appointments do not specify whether the patient could bring a relative ${ }^{39,40}$. Attending a diabetes appointment together may provide a platform for family discussion about the best way to manage dietary needs. 


\section{Study limitations}

383 The current study has several limitations that should be considered. Sampling bias cannot be 384 excluded as participants who took part in the interviews contacted the researcher so it is not clear 385 whether people who volunteer to take part, have different characteristics from people who are 386 randomly chosen. In addition, all participants were white and living in the UK so the findings are not 387 transferable to other countries. A recent study in 5 European countries shows that gender 388 differences in relation to diet management may be particularly evident in Spain and Greece ${ }^{41}$. The 389 390

\section{Conclusion}

The current study suggests that women (whether with type 2 diabetes or relatives) may be more likely to prioritise the needs of their family and take an active role in relation to diet management. This is consistent with previous findings on gender and diet management in diabetes. The study 400 builds on previous work by showing that traditional gender roles, where women are responsible for 401 food preparation, may be still prevalent in the UK. Family-based interventions should focus on the 402 role of gender when adapting to chronic illness. While the results in this paper are drawn from 403 secondary analysis, they provide meaningful contribution to existing literature on gender and diet management in relation to type 2 diabetes.

\section{References}

$406{ }^{1}$ Wermeling, PR., Gorter, KJ., van Stel, HF. \& Rutten, GE. (2012). Both cardiovascular and non-

407 cardiovascular comorbidity are related to health status in well-controlled type 2 diabetes patients: A 408 cross-sectional analysis. Cardiovascular Diabetology, 11.

4102 Diabetes UK (2019). Eating well with diabetes. Available from https://www.diabetes.org.uk/guideto-diabetes/enjoy-food/eating-with-diabetes Accessed 23.07.2019 
414 Diabetes Distress and Diet-Related Interactions of Married Patients With Diabetes and Their Spouses. Families, Systems \& Health, 30 (2), 154-165.

416

${ }^{4}$ Wen, LK., Shepherd, MD. \& Parchman, ML. (2004). Family Support, Diet, and Exercise Among Older 418 Mexican Americans With Type 2 Diabetes. The Diabetes Educator, 30 (6), 980-993.

419

420

${ }^{5}$ Gallant, M. (2003). The Influence of Social Support on Chronic Illness Self-Management: A Review 421 and Directions for Research. Health Education \& Behavior, 30 (2), 170-195.

422

${ }^{6}$ Revenson, T., Abraído-Lanza, Ana., Majerovitz, D. \& Jordan, C. (2005). Couples Coping With Chronic 424 Illness: What's Gender Got to Do With It? In T. Revenson, K. Kayser, G. Bodenmann (Eds) Couples coping with stress: Emerging perspectives on dyadic coping (pp. 137-156). Washington, DC, 426 US: American Psychological Association.

427

${ }^{7}$ Bianchi, S. M., Sayer, L. C., Milkie, M. A. \& Robinson, J.P. (2012). Housework: Who Did, Does or Will Do It, and How Much Does It Matter? Social Forces, 91, 55-63.

430

${ }^{8}$ Spitze, G. \& Ward, R. (2000). Gender, Marriage, and Expectations for Personal Care. Research on aging, 22, 451-469.

433

${ }^{9}$ Maclean, H. (1991). Patterns of diet related self-care in diabetes. Social Sciences and Medicine, 32 435 (6), 689-696.

436

$437{ }^{10} \mathrm{Li}$, J., Drury, V. \& Taylor, B. (2014). Systematic review of the experience of older women living and 438 coping with type 2 diabetes. International Journal of Nursing Practice, 20, 126-134.

${ }^{11}$ Mathew, R., Gucciardi, E., Del Melo, M. \& Barata, P. (2012). Self-management experiences among 441 men and women with type 2 diabetes mellitus: a qualitative analysis. BMC Family Practice, 13.

${ }^{12}$ Hara, Y., Hisatomi, M., Ito, H., Nakao, M., Tsuboi, K. \& Ishihara, Y. (2014). Effects of gender, age, 444 family support, and treatment on perceived stress and coping of patients with type 2 diabetes 445 mellitus. BioPsychoSocial Medicine, 8 (16). 
$447{ }^{13}$ Wexler, DJ., Grant, RW., Meigs, JB., Nathan, DM. \& Cagliero, E. (2005). Sex disparities in treatment 448 of cardiac risk factors in patients with type 2 diabetes. Diabetes Care, 28, 514-520.

449

450

${ }^{14}$ Tuomilehto, J., Rastenyte, D., Jousilahti, P., Sarti, C \& Vartiainen. (1996). Diabetes mellitus as a risk 451 factor for death from stroke. Prospective study of the middle-ages Finnish population. Stroke, 27, 452 210-215.

453

${ }^{15}$ Bédard, M., Kuzik, R., Chambers, L., Molloy, DW., Dubois, S., \& Lever, JA. (2005). Understanding 455 burden differences between men and women caregivers: the contribution of care-recipient problem 456 behaviors. International Psychogeriatrics, 17 (1), 99-118.

457

${ }^{16}$ Fort, MP., Castro, M., Peña, L., Hernández, SHL., Camacho, GA., Ramírez-Zeam, M. \& Martínez, H. 459 (2015). Opportunities for involving men and families in chronic disease management: a qualitative 460 study from Chiapas, Mexico. BMC Family Practice, 15.

461

$462{ }^{17}$ Ansari, RM., Hosseinzadeh, H., Harris, M. \& Zwar, N. (2019). Self-management experiences among 463 middle-aged population of rural area of Pakistan with type 2 diabetes: A qualitative analysis. Clinical 464 Epidemiology and Global Health, 7, 177-183.

465

466

${ }^{18}$ Samuel-Hodge, CD., Headen, SW., Skelly, AH., Ingram, AF., Keyserling, TC., Jackson, EJ. Ammerman, 467 AS. \& Elasy, TA. (2000). Influences on day-to-day self-management of type 2 diabetes among African468 American women. Spirituality, the multi-caregiver role, and other social context factors. Diabetes Care, 23, 928-933.

470

${ }^{19}$ Curtice, J., Clery, E., Perry, J., Phillips M. and Rahim, N. (eds.) (2019), British Social Attitudes: The 36th Report, London: The National Centre for Social Research http://www.gov.scot/Topics/Statistics/SIMD Accessed 21.07.2019

$477 \quad{ }^{21}$ Spencer, L., Ritchie, J., Ormston, R., O'Connor, W. \& Barnard, M. (2014). Analysis: Principles and 478 processes. In J. Ritchie, J. Lewis, C. Nicholls, R. Ormston (Eds) Qualitative research practice. A guide 479 for Social Science students and researchers. SAGE Publications. 
48122 Lacey, A. \& Luff, D. (2007). Qualitative data analysis. The NIHR RDS for the East Midlands /

482 Yorkshire \& the Humber.

483

$484 \quad{ }^{23}$ Beverly, E.A. \& Wray, L. A. (2010). The role of collective efficacy in exercise adherence: a

485 qualitative study of spousal support and Type 2 diabetes management. Health Education Research, $48625(2), 211-223$.

487

488

${ }^{24}$ Berg, CA. \& Upchurch, R. (2007). Developmental-Contextual Model of Couples Coping With 489 Chronic Illness Across the Adult Life Span. Psychological Bulletin, 133 (6), 920-954.

490

$491 \quad{ }^{25}$ Bodenmann, G. (2005). Dyadic coping and its significance for marital functioning. In T. Revenson, 492 K. Kayser, \& G. Bodenmann (Eds.), Couples coping with stress: Emerging perspectives on dyadic 493 coping (pp. 33 - 50). Washington, DC: American Psychological Association.

494

495

${ }^{26}$ del Rio-Lozano, M., Garcia-Calvente, Mdel M., Marcos-Marcos, J., Entrena-Durán, F., Maroto496 Navarro, G. (2013). Gender Identity in Informal Care: Impact on Health in Spanish Caregivers. 497 Qualitative Health Research, 23 (11), 1506-1520.

498

499

27 Bourdieu, P. (1998). Masculine domination. Stanford: Stanford University of Press.

500 Carmichael, F. \& Charles, S. (2003). The opportunity costs of informal care: does gender matter? 501 Journal of Health Economics, 22, 781-803.

502

$503{ }^{28}$ Carmichael, F. \& Charles, S. (2003). The opportunity costs of informal care: does gender matter?

504 Journal of Health Economics, 22, 781-803.

505

$506{ }^{29}$ Figueiredo, D., Jacome, C., Gabriel, R., Marques, A. (2016). Family care in chronic obstructive 507 pulmonary disease: what happens when the carer is a man? Scandinavian Journal of Caring Sciences, $50830,721-730$.

509

$510{ }^{30}$ Navaie-Waliser, M., Spriggs, A., \& Feldman, P. (2002). Informal caregiving. Differential experiences 511 by gender. Medical Care, 40, 1249-1259.

512 
$513{ }^{31}$ Martire, LM., Lustig, AP., Schulz, R., Miller, G., Helgeson, VS. (2004). Is it beneficial to involve a 514 family member? A meta-analysis of psychosocial interventions for chronic illness. Health Psychology, 515 23 (6), 599-611.

516

$517 \quad{ }^{32}$ Armour, TA., Norris, SL., Jack Jr, L., Zhang, X. \& Fisher, L. (2005). The effectiveness of family 518 interventions in people with diabetes mellitus: a systematic review. Diabetic Medicine, 22, 12955191305.

520

52133 Michie, S., Richardson, M., Johnston, M., Abraham, C., Francis, J., Hardeman, W., Eccles, M. P., 522 Cane, J. and Wood, C. E. (2013). The Behavior Change Technique Taxonomy (v1) of 93 Hierarchically 523 Clustered Techniques: Building an International Consensus for the Reporting of Behavior Change 524 Interventions. Annals of Behavioral Medicine, 46, pp. 81-95.

525

${ }^{34}$ Falconier, M. (2013). Traditional gender role orientation and dyadic coping in immigrant Latino couples: Effects on couple functioning. Family Relations, 62, 269-283.

528

${ }^{35}$ Siddiqul, MA., Khan, MF. \& Carline, TE. (2013). Gender differences in living with diabetes mellitus. 530 Materia Socio Medica, 25(2), 140-142.

531

${ }^{36}$ Carter-Edwards, L., Skelly, AH., Cagle, CS. \& Appel, SJ. (2004). "They care but don't understand": Family support of African American women with type 2 diabetes. The Diabetes Educator, 30 (3), 493501.

535

${ }^{37}$ Van Boemal, GB. \& Paul, P. (1999). Effects of adherence to traditional female sex roles on compliance with diabetic regimens. Journal of visual impairment and blindness, 93(1), 432-439. Religion. Available from https://www.scotlandscensus.gov.uk/ethnicity-identity-language-andreligion Accessed 23.07.2019

542

$543{ }^{39}$ NHS (2019). Going for regular check-ups: Type 2 diabetes. Available from

544 https://www.nhs.uk/conditions/type-2-diabetes/going-regular-check-ups/_Accessed 23.07.2019 
$546{ }^{40}$ Diabetes UK (2019). Diabetes Clinics. Available from https://www.diabetes.org.uk/guide-to-

547 diabetes/young-adults/diabetes-clinics_Accessed 23.07.2019

548

$549{ }^{41}$ Knutsen, IR., Foss, IC., Todorova, E., Roukova, P., Kennedy, A., Portillo, MC., Regaira, E. et al.

550 (2015). Negotiating diet in networks: a cross-European study of experiences of managing type 2

551 diabetes. Qualitative Health Research, 1-12.

552

553

554

555

Table 1. Participants' characteristics

\begin{tabular}{|c|c|c|}
\hline & People with type 2 diabetes & Relatives \\
\hline № & 10 & 13 \\
\hline Duration of type 2 diabetes & $\begin{array}{l}\text { Range: } 3 \text { weeks }-18 \text { months } \\
\text { Mean: } 7.9 \text { months } \\
\text { Median: } 6.5 \text { months }\end{array}$ & - \\
\hline Route to diagnosis & $\begin{array}{l}5 \text { presenting GP with } \\
\text { symptoms; } 3 \text { periodic } \\
\text { screening; } 1 \text { visit GP for other } \\
\text { reasons; } 1 \text { after gestational } \\
\text { diabetes }\end{array}$ & - \\
\hline $\begin{array}{l}\text { Relationships with the person } \\
\text { with type } 2 \text { diabetes }\end{array}$ & - & $\begin{array}{l}6 \text { daughters, } 3 \text { wives, } 2 \\
\text { husbands, } 1 \text { son, } 1 \text { mother. } \\
6 \text { share genetics but live apart } \\
\text { from the person with type } 2 \\
\text { diabetes } \\
2 \text { share genetics and live } \\
\text { together } \\
5 \text { do not share genetics and } \\
\text { live together }\end{array}$ \\
\hline Gender & 5 male, 5 female & 10 female, 3 male \\
\hline Age & $\begin{array}{l}\text { Range: } 37-71 \text { years } \\
\text { Mean: } 53.6 \text { years } \\
\text { Median: } 51 \text { years }\end{array}$ & $\begin{array}{l}\text { Range: } 18-68 \text { years } \\
\text { Mean: } 41.17 \text { years } \\
\text { Median: } 45.5 \text { years }\end{array}$ \\
\hline
\end{tabular}




\begin{tabular}{|c|c|c|}
\hline $\begin{array}{l}\text { SIMD (Scottish Index of } \\
\text { Multiple Deprivation) }\end{array}$ & $\begin{array}{l}\text { Range: } 2-10 \\
\text { Median: } 6\end{array}$ & $\begin{array}{l}\text { Range: } 2-10 \\
\text { Median: } 6\end{array}$ \\
\hline Education & $\begin{array}{l}9 \text { had education after high } \\
\text { school ( } 2 \text { PhD, } 1 \text { MSc, } 2 \\
\text { BAs/BSc, } 1 \text { one year at } \\
\text { university, } 1 \text { Diploma, } 1 \text { Police } \\
\text { promotion exam, } 1 \text { HNC, } \\
2 \text { current students) }\end{array}$ & $\begin{array}{l}9 \text { had education after high } \\
\text { school ( } 3 \text { PhD, } 1 \mathrm{MSc}, 2 \\
\text { BAs/BSc, } 2 \text { college, } 1 \text { SHND, } \\
3 \text { current students) }\end{array}$ \\
\hline Employment & $\begin{array}{l}4 \text { full-time, } 3 \text { retired, } 2 \\
\text { unemployed, } 1 \text { part-time }\end{array}$ & $\begin{array}{l}4 \text { full-time, } 4 \text { part-time, } 2 \\
\text { unemployed, } 1 \text { self-employed, } \\
1 \text { retired, } 1 \text { other }\end{array}$ \\
\hline Relationship status & 8 in a relationship, 2 single & 12 in a relationship, 1 single \\
\hline Family history of diabetes & $\begin{array}{l}5 \text { yes, } 5 \text { no } \\
\text { Number of relatives with } \\
\text { diabetes: } 1-4\end{array}$ & $\begin{array}{l}8 \text { yes, } 5 \text { no } \\
\text { Number of relatives with } \\
\text { diabetes: } 1 \text { - } 4\end{array}$ \\
\hline $\begin{array}{l}\text { How they heard about the } \\
\text { study }\end{array}$ & $\begin{array}{l}5 \text { word of mouth (relative who } \\
\text { took part or someone who saw } \\
\text { advert) } \\
2 \text { University of Stirling portal } \\
1 \text { Diabetes UK newsletter } \\
1 \text { Poster at a community } \\
\text { centre } \\
1 \text { Local Diabetes support group } \\
\text { social media page }\end{array}$ & $\begin{array}{l}7 \text { word of mouth (through } \\
\text { someone who took part or } \\
\text { someone who saw advert) } \\
2 \text { University of Stirling email } \\
\text { advert } \\
2 \text { University of Stirling portal } \\
2 \text { Local council intranet }\end{array}$ \\
\hline
\end{tabular}

Table 2. Participants and form of interview

\begin{tabular}{|c|c|}
\hline Form of interview & $\begin{array}{l}\text { Participants' characteristics in the context of } \\
\text { the study }\end{array}$ \\
\hline Interviewed together & $\begin{array}{l}\text { A man with type } 2 \text { diabetes (I2P1, } 55 \text { years old, } \\
6 \text { months since diagnosis), his wife (I2R3, } 54 \\
\text { years old) and daughters (I2R2, } 23 \text { years old } \\
\text { and I2R4, } 20 \text { years old). } \\
\text { A man with type } 2 \text { diabetes (I3P2, } 47 \text { years old, } \\
2 \text { months since diagnosis) and his wife (I3R5, } 46 \\
\text { years old). }\end{array}$ \\
\hline
\end{tabular}




\begin{tabular}{|c|c|}
\hline & $\begin{array}{l}\text { A man with type } 2 \text { diabetes (I6P4, } 70 \text { years old, } \\
3 \text { months since diagnosis) and his wife (I6R7, } 60 \\
\text { years old). }\end{array}$ \\
\hline Interviewed separately & $\begin{array}{l}\text { A woman with type } 2 \text { diabetes (I4P3, } 39 \text { years } \\
\text { old, } 7 \text { months since diagnosis) and her husband } \\
\text { (I8R8, } 47 \text { years old). } \\
\text { A woman with type } 2 \text { diabetes (I10P6, } 65 \text { years } \\
\text { old, } 6 \text { months since diagnosis) and her daughter } \\
\text { (I11R10, } 29 \text { years old). } \\
\text { A woman with type } 2 \text { diabetes (I13P7, } 60 \text { years } \\
\text { old, } 10 \text { months since diagnosis) and her } \\
\text { husband (I13R12, } 60 \text { years old). } \\
\text { A daughter of a man with type } 2 \text { diabetes } \\
\text { (I16R13, } 45 \text { years old) and her parents (I6P4, } \\
\text { I6R7). }\end{array}$ \\
\hline Interviewed alone (relative did not take part) & $\begin{array}{l}\text { A woman with type } 2 \text { diabetes (I7P5, } 45 \text { years } \\
\text { old, } 3 \text { weeks since diagnosis). } \\
\text { A woman with type } 2 \text { diabetes (I14P8, } 47 \text { years } \\
\text { old, } 18 \text { months since diagnosis). } \\
\text { A man with type } 2 \text { diabetes (I15P9, } 37 \text { years } \\
\text { old, } 8 \text { months since diagnosis). } \\
\text { A man with type } 2 \text { diabetes (I17P10, } 71 \text { years } \\
\text { old, } 18 \text { months since diagnosis). } \\
\text { A mother of a man with type } 2 \text { diabetes (I1R1, } \\
68 \text { years old, son diagnoses in the past } 6 \\
\text { months). } \\
\text { A daughter of a man with type } 2 \text { diabetes (I5R6, } \\
18 \text { years old, father diagnosed } 8 \text { months ago). } \\
\text { A daughter of a man with type } 2 \text { diabetes (I9R9, } \\
\text { age not reported, father diagnosed } 6 \text { weeks } \\
\text { ago). } \\
\text { A son of a man with type } 2 \text { diabetes (I12R11, } 24 \\
\text { years old, father diagnosed } 11 \text { months ago). }\end{array}$ \\
\hline
\end{tabular}

